\title{
Case Study of Baiyun and Caohai Lakes Implies How to Implement Wetland Restoration/Creation
}

\author{
Lin Xiao ${ }^{*}$, Qun Zhang1, Guifeng Wei ${ }^{1}$, Sixi Zhu ${ }^{2 *}$, Fanyang Yu ${ }^{3}$, Boping Han ${ }^{1}$ \\ ${ }^{1}$ Ecology Department, Jinan University, Guangzhou, China \\ ${ }^{2}$ College of Eco-Environmental Engineering, Guizhou Minzu University, Guiyang, China \\ ${ }^{3}$ Guangzhou Water Science Research Institute, Guangzhou, China \\ Email: *spray_80@foxmai.com, *zhusixi2011@163.com
}

How to cite this paper: Xiao, L., Zhang, Q., Wei, G.F., Zhu, S.X., Yu, F.Y. and Han, B.P. (2018) Case Study of Baiyun and Caohai Lakes Implies How to Implement Wetland Restoration/Creation. Open Access Library Journal, 5: e4896.

https://doi.org/10.4236/oalib.1104896

Received: September 10, 2018

Accepted: October 21, 2018

Published: October 24, 2018

Copyright $\odot 2018$ by authors and Open Access Library Inc.

This work is licensed under the Creative Commons Attribution International License (CC BY 4.0).

http://creativecommons.org/licenses/by/4.0/

\begin{abstract}
This work discusses how to implement wetland restoration/creation from the viewpoint that wetland aquatic plants are divided into four life forms: emergent, submergent, floating and floating leaf plants. Caohai Lake and Baiyun Lake were selected to discuss the difference of the species richness changes during the creation/restoration process. Baiyun Lake and eight surrounding wetlands have been selected to discuss how the species richness, the dispersal and the colonization potential among four plant life forms affect the species richness changes and community restoration in the target wetland. The community composition changes in the introduced single dominant submergent and emergent plant community in Baiyun Lake have also been tracked to discuss how invasive plants' dispersal affects wetland restoration/creation. The result indicated that in the process of creation/restoration of Caohai Lake and Baiyun Lake, the emergent plants have been increasing, while the submergent, the floating and the floating leaf plants began to increase and then maintained a dynamic balance. The similarity of plant community composition between the target wetland Baiyun Lake and the surrounding wetlands increased gradually, which was mainly affected by distance and river-lake connectivity. In the natural wetlands, the most common plants are emergent plants, which account for approximately 80 percent of wetland plants; this implies a greater abundance of germplasm resources, dispersal and colonization potential of emergent plants than the other three plant life forms. In Baiyun Lake, invasive plants mainly affect the introduced emergent plants community. The study confirms that before implementing wetland restoration/creation, pre-restoration surveys are required to the target wetland and its surrounding wetland. The study also finds that in Guangdong province,
\end{abstract}


China, the restoration of wetland vegetation should give more priority to the submergent plants. Generally emergent plants community's invasive preventing and submergent plants germplasm resources introducing will be the focus of the human intervention in wetland restoration/creation.

\section{Subject Areas}

Biodiversity, Ecology, Environmental Sciences, Environmental Sciences, Plant Science

\section{Keywords}

Wetland Restoration, Community Composition, Emergent Plants, Submergent Plants, Dispersal and Colonization Potential

\section{Introduction}

There are usually two approaches to the creation/restoration of a wetland ecosystem. One is "self-design"; the other, more commonly used approach is "biological engineering" [1] [2]. Self-design's emphasis is on the concept that the wetland system itself will optimize its design by selecting for the assemblage of plants, microbes, and animals best adapted to existing conditions, but only if sufficient propagules can enter the system [3] [4]. Biological engineering involves the introduction of specific plants, whose survival becomes the measure of success for the restoration [1]. For a wetland, successful creation/restoration systems will eventually be indistinguishable whether started with self-design or biological engineering [1] [5] [6]. Self-designed systems may require more time to reach the creation/restoration destination, while biological engineering often leads to failed creation/restoration efforts or encourages practices that oppose the goal of a sustainable landscape [1] [5] [7]. From the perspective of self-designed systems, the entry of species is mainly through natural spread [1], but the introduction of aquatic plants by human can accelerate aquatic plant community succession in the initial succession stages of wetland restoration [8]. Therefore, semi self-design has been proposed and is given more attention compared to biological engineering processes [9]. To achieve semi self-design, it needs the wetland itself to play the role of autonomic regulator, meanwhile the human interference promotes the restoration of wetland vegetation. The question remains: what work should be given to nature and which jobs need human involvement?

Considering that self-design and biological engineering are both based on the entry of species [1], understanding the dispersal and colonization potential of aquatic plants may be helpful to wetland vegetation restoration [10] [11] [12]. The main factors influencing aquatic plant dispersal and colonization include the effectiveness of seed transmission, as well as the amount of seed available for transmission. Regarding methods of transmission, most aquatic species are considered zoochorous [13] [14] [15] and are mediated by birds [15] [16]; other 
seed dispersal methods include hydrochory [16] [17] [18], wind [19], and anthropochory (dispersal by man), which is the most influential of all the dispersal mechanisms [18]. While asexual propagules are probably of importance to short-distance and local dispersal, sexual propagules are more likely to result in regional and long-distance dispersal [11] [20]. Although there are many strategies for transmission, spreading the germplasm resources of aquatic plants may be the bottleneck for the natural restoration of wetland habitats [21], as effective dispersal rates may be much lower than generally accepted values for aquatic species [20]. This means that the propagule numbers and species abundance, which can be seen as the dispersal potential for aquatic plants in the surrounding wetland, will affect the target wetland's restoration/creation.

As species are continually enter into and begin to colonize a landscape, species richness usually initially increases [22], as in the Napahai wetland, where the vegetation in the lakeside zone increased from 14 species to 26 species after 8 years of restoration [23]. The species' continual introduction by natural methods gives self-designed wetland systems significant opportunity to adjustment themselves [24]. As result, the structural characteristics of the vegetation of the created/restored wetland will become similar to those in a natural wetland after only a few years [25]. These results indicate that the recovery of wetland vegetation is a gradual process of species increasing. But for the process, few study give attention to the species richness change of different kinds of life forms aquatic plants.

Wetland aquatic plants are divided into 4 kinds of life forms according to the position of the roots relative to the soil and the position of the leaves relative to the water surface: emergent plants, part stems and leaves pierces the water surface with root attached to the substrate; submergent plants, completely grow under water with root attached to the substrate; floating plants, stream and leaves that float on the water surface without root attached to the substrates; and floating leaf plants, stream and leaves that float on the water surface with root attached to the substrates [26]. Now, few knowledge about the differences in the propagule abundance, dispersal and colonization potential of these four aquatic plant forms in a natural wetland and how do the differences affect wetland restoration/creation, also few knowledge about the species richness change of these four aquatic plant forms during wetland vegetation restoration.

We assume that there are exist the differences in the germplasm resources' abundance, as well as the dispersal and colonization potential among the four life forms plant in the nature; there are also exist the differences in the species richness increment among the four life forms plant during the wetland restoration process; these will affect the target wetland's plant community restoration and the implementation of wetland restoration/creation

Two restored/created wetlands were selected for use in discussion of the species richness changes in each plant life form during the creation/restoration process: 1) Caohai Lake in Guizhou Province, which was restored over the 35 years since 1981 via self-design; and 2) Baiyun Lake in Guangdong Province, 
which was constructed over 6 years via biological engineering. Baiyun Lake and the eight different types of wetland surrounding it were selected to enable discussion of how surrounding wetlands affect the species richness changes in the target wetland and how the differences in the germplasm resources' abundance, as well as the dispersal and colonization potential among the four plant life forms in the natural setting surrounding the wetland, affect the target wetland's plant community restoration. The community composition changes in the introduced single dominant plant community in Baiyun Lake have also been tracked to discuss how natural species dispersal affects wetland restoration/creation, especially for invasive species. Lastly, implementing guidelines for wetland restoration/creation have been proposed according to the advantages and disadvantages of biological engineering and self-design.

\section{Methods}

\subsection{Wetland Plant Community Composition Changes during Wetland Restoration/Creation}

\subsubsection{Study Site}

The wetland plant species changes during the restoration of Baiyun Lake in Guangdong Province have been studied and have been compared with those of Guizhou Province's Caohai Lake, which has been restored by self-design over 35 years.

Figure 1 shows the geographical location and shape of Baiyun lake. It is located in the northwest of Baiyun District (N23 $\left.{ }^{\circ} 13^{\prime}, \mathrm{E} 113^{\circ} 12^{\prime}\right)$ of Guangzhou city. It belongs to a maritime subtropical monsoon climate, with an annual average rainfall of approximately $1720 \mathrm{~mm}$ and an annual average temperature $20^{\circ} \mathrm{C}$ $22^{\circ} \mathrm{C}$. Baiyun Lake is the largest artificial lake in Guangzhou, which was constructed over a period of 6 years (up to 2016), composed of an eastern side and a western side. The east lake's water area is $0.66 \mathrm{~km}^{2}$, while the west lake's water area is $0.36 \mathrm{~km}^{2}$, both lakes with a maximum depth of approximately $3.5 \mathrm{~m}$. The lake's water is sourced from Pearl River through pumping (the inlet water is Grade V: mainly suitable for agricultural water area and general landscape waters, while the intake place is close to an efflux of Liuxi River into Pearl River) and flows first into the west lake, after purification by sedimentation and plant absorption, it moves into the east lake, receives the plant absorption again in the east lake and is introduced into the Shijin River. The lake's construction began in December 2006 and was completed in April 2010. In the beginning, only some of the emergent plants were planted in the lakeshore area, and in 2013, small patches of Vallisneria natans were additionally planted in the closed shallow water. In 2016, a new submergent plant community restoration project was implemented, and Hydrilla verticillata, Potamogeton wrightii, Myriophyllum spicatum, Ceratophyllum demersum and more Vallisneria natans were planted in the closed lakeshore area.

Figure 1 shows the geographical location and shape of Caohai lake, which located in Weining County, west of Guizhou Province (N26 $47^{\prime} 32-26^{\circ} 52^{\prime} 52^{\prime \prime}$, 


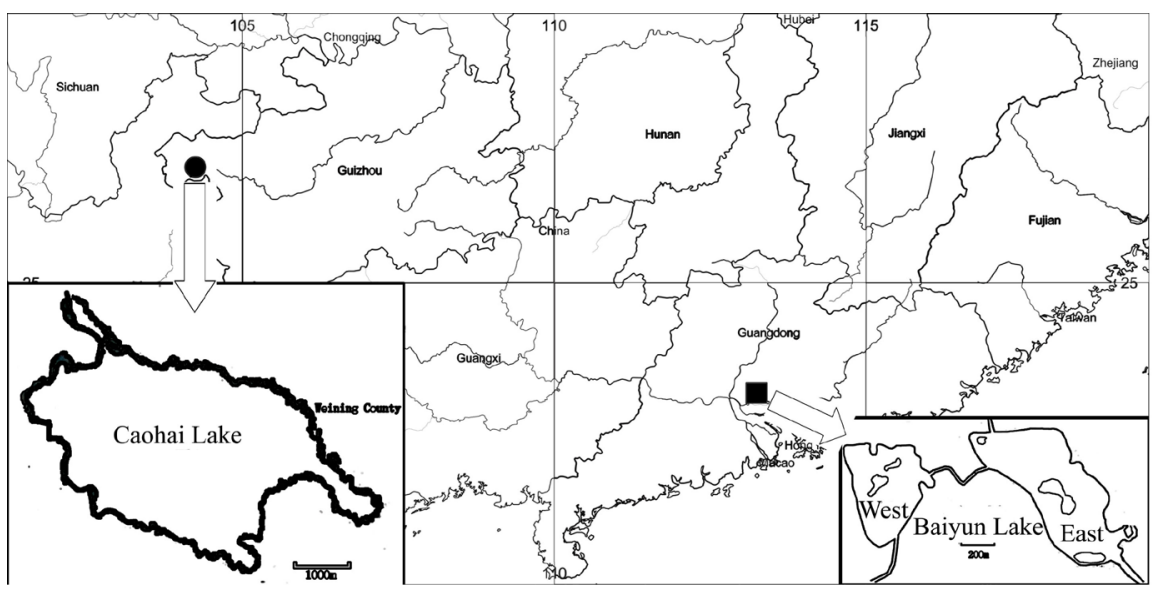

Figure 1. The location of Baiyun Lake in Guangdong Province and Caohai Lake in Guizhou Province. $\mathbf{~ : ~ B a i y u n ~ L a k e , ~ \bullet : ~ C a o h a i ~ L a k e . ~ M a p p e d ~ b y ~ S i m p l e M a p p r ~}$ (http://www.simplemappr.net/).

E104 ${ }^{\circ} 16^{\prime} 10^{\prime \prime}-104^{\circ} 20^{\prime} 40^{\prime \prime}$, at an altitude of $2171.7 \mathrm{~m}$ ). Caohai Lake is a completely and typically karst plateau shallow lake and wetland. It had been drained of water in the 1970s; then, the government decided to restore it in 1981, and the water level had been recovered in 1982. Currently, the wetland's water area is approximately $19.8 \mathrm{~km}^{2}$, with a maximum depth approximately $3 \mathrm{~m}$; however, the average water depth less is than 1.5; the lake's water is alkaline ( $\mathrm{pH} 8.0$ ). Caohai Lake belongs to a temperate climate, with an annual average rainfall of approximately $950.9 \mathrm{~mm}$ and an annual average temperature $10.5^{\circ} \mathrm{C}$.

\subsubsection{Vegetation Data Collection}

Vegetation data for Caohai Lake includes two parts, as showed in Table S1. One part comes from our investigation, conducted in June, July and October of 2015 and in January, April, July of 2016; the other part is historical vegetation data found in surveys from 1983 [27], 2005 [28], and 2013 [29]. In our vegetation survey, vegetation was assessed using a line-intercept method. To compare with historical data, the line-intercept corresponding to the study site in 1983 and 2005 was used. Vegetation data for Baiyun Lake come from our investigation, only east lake vegetation had been involved in this study. It was conducted in July 2013 and again in April 2014, April 2016 and July 2016 using the line-intercept technique.

In the line-intercept technique, the wetland plant species name, frequency and abundance have been recorded; species have been photographed.

\subsection{The Comparison of Community Composition Structures between the Restored/Created Wetland and the Surrounding Natural Wetland}

\subsubsection{Study Site}

To compare the plant community composition between the restored wetland and the surrounding natural wetland, vegetation surveys of Baiyun Lake and the other 8 surrounding wetlands in Guangdong Province were conducted. Figure 2 


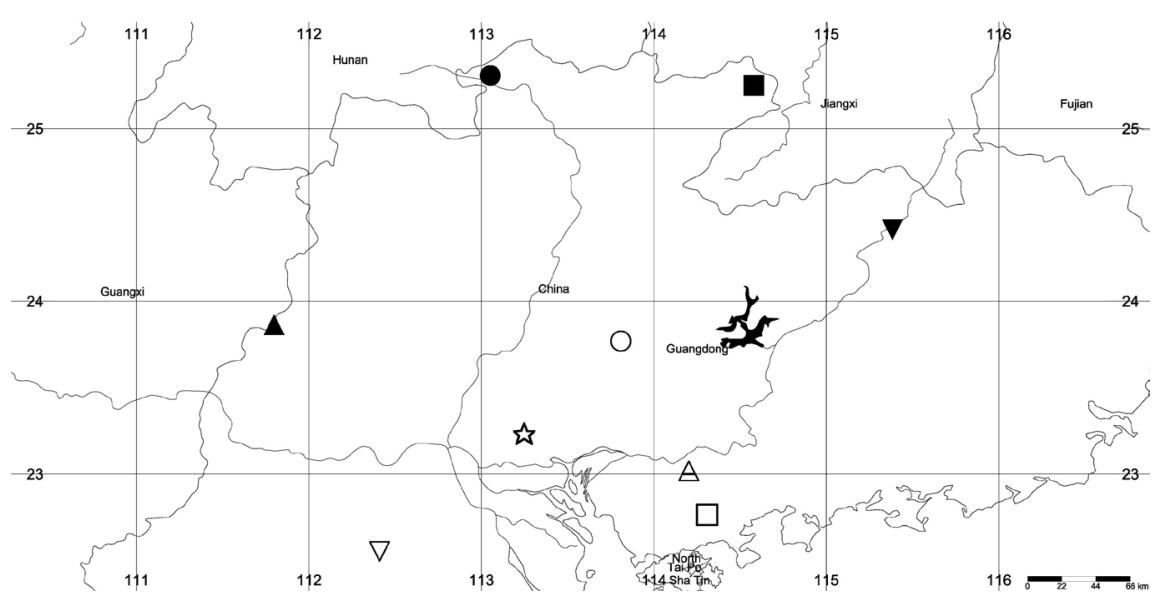

Figure 2. The location of Baiyun Lake and the other 8 surrounding wetlands in Guangdong Province. $\lesssim$ : Baiyun Lake (BL), $\square$ : Longgang River (LG), $\Delta$ : Tong Lake (TL), ○: Liuxi River (LX), $\nabla$ : Dashahe Reservoir (DS), $\boldsymbol{\Delta}$ : He Jiang upstream (HJ), •: Wu Jiang upstream (WJ), $\mathbf{-}$ : Zhen Jiang upstream (ZJ), $\mathbf{\nabla}$ : Dong Jiang upstream (DJ). Mapped by SimpleMappr (http://www.simplemappr.net/).

shows the geographical location of this 9 wetlands. Four wetlands were close to Baiyun Lake: the Dashahe Reservoir wetland (DS, reservoir wetland, approximately $115 \mathrm{~km}$ from Baiyun Lake), the Liuxi River wetland (LX, riverine wetland, approximately $80 \mathrm{~km}$ from Baiyun Lake), the Tong Lake watershed wetland (TL, mixed pool and river wetlands, approximately $100 \mathrm{~km}$ from Baiyun Lake) and the Longgang River wetland (LG, riverine wetland, approximately 115 $\mathrm{km}$ from Baiyun Lake). The other four wetlands, farther away from Baiyun Lake, include the He Jiang upstream wetland (HJ, river and farmland mixed wetlands, approximately $210 \mathrm{~km}$ from Baiyun Lake), the $\mathrm{Wu}$ Jiang upstream wetland (WJ, river and farmland mixed wetland, approximately $250 \mathrm{~km}$ from Baiyun Lake), the Zhen Jiang upstream wetland (ZJ, river and farmland mixed wetland, approximately $260 \mathrm{~km}$ from Baiyun Lake) and the Dong Jiang upstream wetland (DJ, river and farmland mixed wetland, approximately $300 \mathrm{~km}$ from Baiyun Lake).

\subsubsection{Vegetation Data Collection}

Vegetation was assessed using a line-intercept method. Each investigation of the 8 surrounding wetlands lasted approximately two days: driving, when the road is close to the water, stopping, investigating and taking plant photos for approximately 30 minutes, line-intercept was done between 2013 and 2016, while the Liuxi River wetland had an additional vegetation survey in June 2017. The line-intercept included the wetland plant species name, abundance records, and all photos taken of the investigated species. Additionally, there are special concerns about invasive species in the wetlands.

In the Baiyun Lake wetland, only the eastern lake vegetation had been researched. This investigation had been conducted in July 2013 and April 2014, as well as April 2016 and July 2016, using the line-intercept technique. 


\subsection{The Community Composition Changes in the Community of Introduced Plants during Vegetation Restoration}

Tracking surveys of the introduced plant community in Baiyun Lake were conducted in 2013 and 2016. In the tracking surveys, the community composition changes of the introduced single dominant plant community were recorded. The introduced single dominant plant community included Cyperus papyrus, Thalia dealbata, Thalia geniculata, Vallisneria natans, Nelumbo nucifera, Nymphaea mexicana, Ludwigia adscendens, Myriophyllum aquaticum, Phragmites australis, Arundo donax, Pontederia cordata, Acorus calamus, Colocasia esculenta, Canna glauca and Echinodorus grisebachii communities.

\subsection{Data Analysis}

The wetland plant species have been divided into 4 kinds of lifeforms: emergent plants (EP, include the plant which part stems and leaves pierces the water surface with root attached to the substrate and the plant which live beside water but the root system is low than the high water level), submergent plants (SP), floating plants (FP) and floating leaf plants (FLP), according to the position of the roots relative to the soil and the position of the leaves relative to the water surface (Sculthorpe 1967). Species abundance was recorded with a 5-level classification: Soe (Sociales, there are a lot of plant and the overground plants are closed), Cop (Copiosae, is numerous), Sp (Sparsal, is small and scattered), Sol (Solitariae, is small and sparse), Un (Unicum, individual or single), quantified as 5, 4, 3, 2 and 1 in Table S2, respectively according to Drude abundance; the species not seen in the survey were recorded as 0 in Table S2. In Table S2, Total Frequency $(T F)$ is the sum of the frequency of the species in the 8 wetlands, while Total Abundance $(T A)$ is the sum of the abundance of the species in 8 wetlands. In this study, plant species that were introduced but not found in the 8 surrounding wetlands were excluded from analysis. The data analysis and figure plot were performed using R language (Definition Version 3.3.3 for Windows). The relationship between Baiyun Lake and the 8 wetlands was evaluated via Jaccard index [30] and Clustering analysis (hclust, ward. D2).

$$
\text { Jaccard index }=c /(a+b-c)
$$

a: The number of species in the A communities; $b$ : The number of species in the $\mathrm{B}$ communities; $\mathrm{c}$ : The number of species both in the A and B communities.

\section{Results}

\subsection{The Species Richness, Frequency and Abundance of Four Plant Life Forms in Baiyun Lake and 8 Surrounding Wetlands}

In the vegetation survey result, 147 species of wetland and aquatic plants were recorded, belonging to 44 families and 90 genera; 120 species of native plants accounted for approximately $40 \%$ of the records of Guangdong Province aquatic and wetland plants, while exotic plants included approximately 27 species, accounting for approximately $18.4 \%$ of the total survey of the plants. The number 
of species of each wetland (except Baiyun Lake) was $44.5 \pm 9.93$ species, and the proportion of exotic plants in each wetland varied from $2.27 \%$ to $24.4 \%$. Under the influence of artificial introduction, the number of species and exotic species of Baiyun Lake are higher than the natural wetland (Table 1 and Table S2).

In the 147 identified species, 9 species were submergent plants, 6 species were floating leaves, 5 species were floating plants and 127 species were emergent plants. Among which, $H$. verticillata, $V$. natans, $P$. wrightii, Potamogeton crispus and Chara vulgaris were the relatively high abundance and frequency submergent plants; Commelina communis, Polygonum lapathifolium, Leersia hexandra, Paspalum paspaloides, Colocasia esculenta, Alternanthera philoxeroides, Polygonum chinense, Bidens pilosa var. radiata and Arundo donax, were the relatively high abundance and frequency emergent plants. In addition to the floating plants, Eichhornia crassipes and Pistia stratiotes, two invasive plants were relatively high in abundance and frequency, and of floating leaf plants, only Ludwigia adscendens were more common (Table S2).

\subsection{The Relationship between Baiyun Lake and 8 Surrounding Wetlands in Guangdong Province}

Figure 3(a) (Clustering analysis) and Figure 3(b) (Jaccard community similarity analysis) showed that in 2013, the wetland plant community composition of Baiyun Lake was more similar to that of the Shenzhen Longgang riverine wetland, which is near Baiyun Lake and in the early stage of wetland vegetation restoration; after three years of recovery, it was more similar to the Liuxi River, which is closest to and interconnected with Baiyun Lake. In general, the community species composition of Baiyun Lake was more similar to that of the Liuxi river, the Shenzhen Longgang riverine wetland, the Tong Lake watershed wetland and the Dashahe Reservoir wetland, the four wetlands near Baiyun Lake; it

Table 1. The summary of line-intercept survey result of Baiyun Lake and 8 surrounding wetlands. a: include 26 cultivation species, b: include 32 cultivation species.

\begin{tabular}{cccccc}
\hline Location & Families & Genera & Species & Exotic Plants & Exotic Plants (\%) \\
\hline BL13 & 27 & 40 & $46 \mathrm{a}$ & 18 & 39.1 \\
BL16 & 32 & 58 & $85 \mathrm{~b}$ & 23 & 26.7 \\
LX & 20 & 50 & 66 & 12 & 18.2 \\
LG & 15 & 27 & 37 & 7 & 18.9 \\
DS & 15 & 33 & 47 & 9 & 19.1 \\
TL & 16 & 32 & 41 & 10 & 24.4 \\
ZJ & 19 & 33 & 48 & 3 & 6.25 \\
WJ & 25 & 36 & 44 & 1 & 2.27 \\
HJ & 17 & 30 & 34 & 7 & 20.59 \\
DJ & 23 & 33 & 39 & 3 & 7.7 \\
Total & 44 & 90 & 147 & 27 & 18.4
\end{tabular}




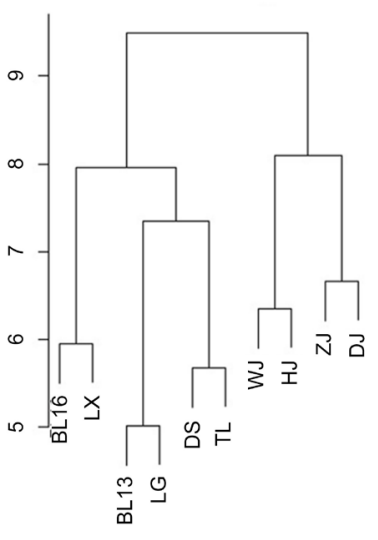

hclust(*,"ward.D2")

(a)

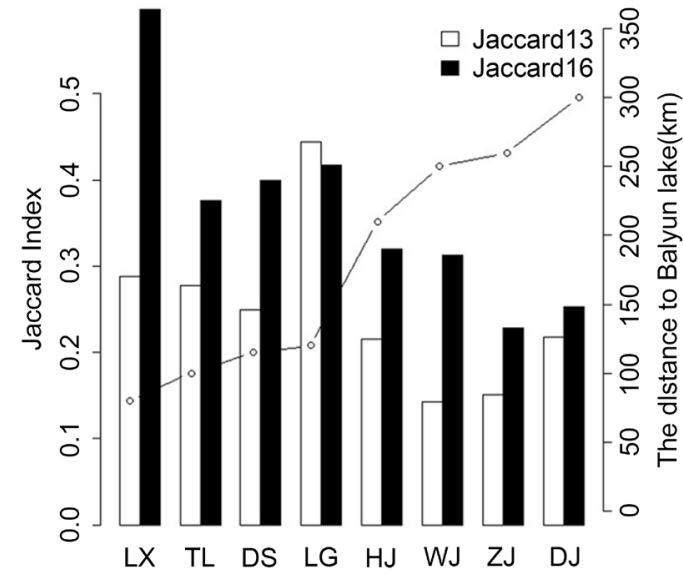

(b)

Figure 3. The species composition clustering analysis results (a) and The Jaccard Community Similarity Index analysis results (b) of Baiyun Lake and 8 surrounding wetlands in Guangdong Province. (BL13: Baiyun Lake 2013, BL16: Baiyun Lake 2016; LX: Liuxi River wetland, LG: Longgang River wetland, DS: Dashahe Reservoir wetland, TL: Tong Lake watershed wetland, ZJ: Zhenjiang River upstream wetland, WJ: Wujiang River upstream wetland, HJ: Hejiang River wetland, DJ: Dongjiang River upstream wetland; GD: all wetlands in Guangdong Province).

is less similar to He Jiang upstream, Wu Jiang upstream, Zhen Jiang upstream and Dong Jiang upstream wetlands, those four wetlands farther away from Baiyun Lake.

\subsection{The Proportion of Different Life Forms of Aquatic Plants in Baiyun Lake, Its 8 Surrounding Wetlands and All Wetlands in Guangdong Province}

Figure 4 showed that in the natural wetlands, the most common wetland plants are emergent plants $(82.49 \% \pm 5.25 \%)$, followed by submergent plants $(6.6 \% \pm$ $3.85 \%)$, floating plants $(6.42 \% \pm 2.69 \%)$ and floating leaf plants $(4.48 \% \pm 1.81 \%)$. In the process of vegetation restoration and succession of the new wetland, Baiyun Lake also maintains similar percentages for the four types of plant life form in the natural wetland.

\subsection{The Four Types of Aquatic Plant and Total Aquatic Plant Richness Changes during Vegetation Restoration}

Figure 5(a) showed that during 2013-2016, the total species in Baiyun Lake increased from 28 to 71 , as the number of emergent plant species increased from 23 to 59, while the other three types of plant life form increased in smaller amounts. Similar to Baiyun Lake, as showed in Figure 5(b) of Caohai Lake, during 1983-2016, the total species number increased from 41 to 79 , as emergent plants increased from 19 to 55. Therefore, in the process of the reconstruction and recovery of wetland plants, emergent plant numbers increased (Figure 5(a), 


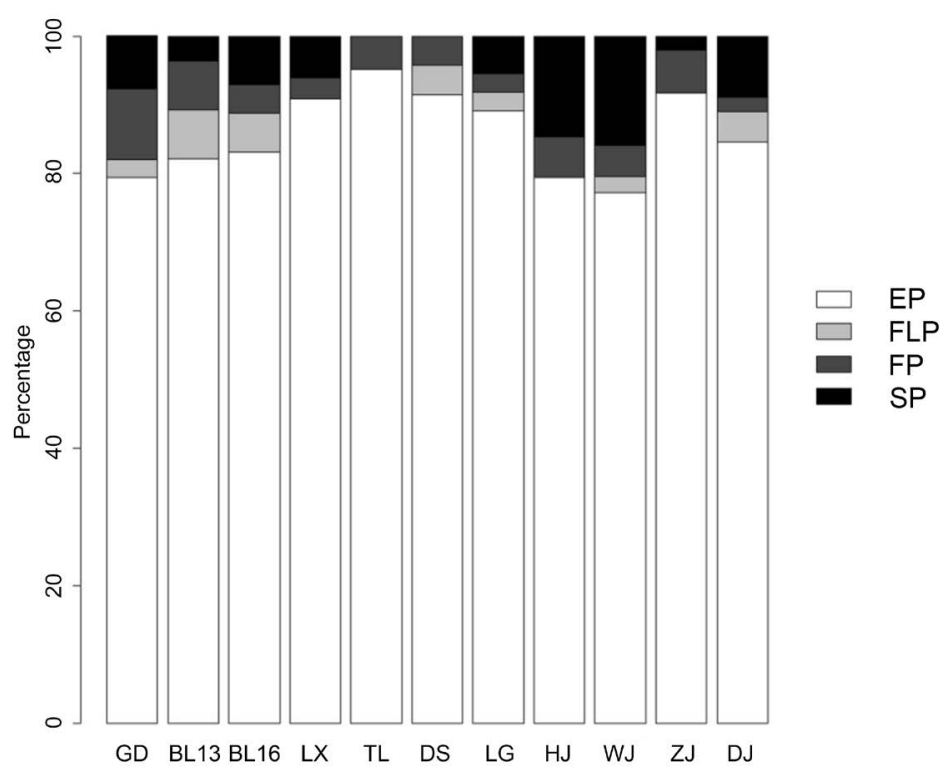

Figure 4. The proportions of different life forms of aquatic plants in Baiyun Lake, 8 surrounding wetlands and all wetlands in Guangdong Province. (BL13: Baiyun Lake 2013, BL16: Baiyun Lake 2016; LX: Liuxi River wetland, LG: Longgang River wetland, DS: Dashahe Reservoir wetland, TL: Tong Lake watershed wetland, ZJ: Zhenjiang River upstream wetland, WJ: Wujiang River upstream wetland, HJ: Hejiang River wetland, DJ: Dongjiang River upstream wetland; GD: all wetlands in Guangdong Province).

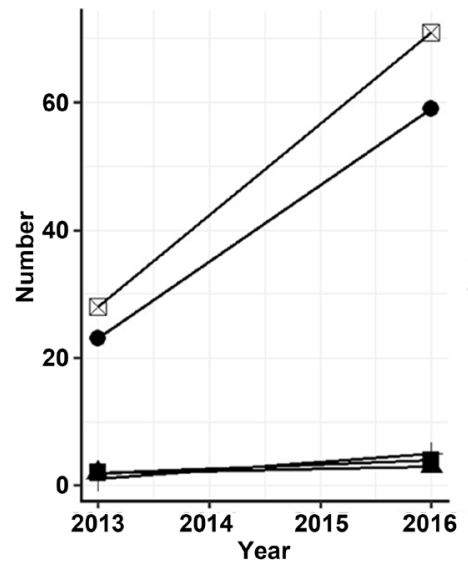

(a)

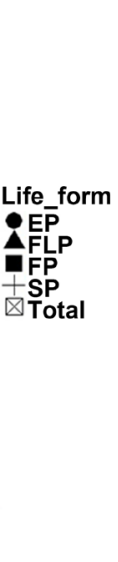

Figure 5. Richness changes of four types of aquatic plant and total aquatic plants for Baiyun Lake (a) and Caohai Lake (b) during vegetation restoration.

Figure 5(b)), while the submergent, the floating and the floating leaf plants also began to increase (Figure 5(a)), and in the end, they became balanced (Figure $5(\mathrm{~b}))$.

\subsection{The Community Composition Change of the Introduced Wetland Plant Community in Baiyun Lake}

According to the tracking survey, as Table 2 demonstrated that from 2013 to 2016, C. papyrus, T. geniculata, V. natans, N. nucifera, N. mexicana, L. adscendens, 
Table 2. The community composition changes of the partial introduced single dominant emergent plant community in Baiyun Lake.

\begin{tabular}{|c|c|c|c|}
\hline \multicolumn{2}{|c|}{ Dominant species } & \multicolumn{2}{|r|}{ Species composition } \\
\hline 2013 & 2016 & 2013 & 2016 \\
\hline P. cordata & A. philoxeroides & P. cordata & $\begin{array}{l}\text { L. crustacea, E. prostrata, A. sessilis, } \\
\text { A. philoxeroides, W. trilobata }\end{array}$ \\
\hline P. cordata & $\begin{array}{l}\text { P. cordata, } \\
\text { H. vulgaris }\end{array}$ & P. cordata & P. cordata, $H$. vulgaris \\
\hline C. prolifer & A. philoxeroides & C. prolifer & $\begin{array}{c}\text { C. prolifer, A. philoxeroides, E. prostrata, } \\
\text { P. distichum }\end{array}$ \\
\hline C. esculenta & W. trilobata & C. esculenta & W. trilobata, C. esculenta \\
\hline A. calamus & W. trilobata & $\begin{array}{l}\text { A. calamus, } \\
\text { W. trilobata }\end{array}$ & A. calamus, W. trilobata, A. philoxeroides \\
\hline C. glauca & $\begin{array}{l}\text { B. pilosa var. } \\
\text { radiata }\end{array}$ & C. glauca & B. pilosa var. radiata, C. glauca \\
\hline E. grisebachii & C. diffusa & E. grisebachii & $\begin{array}{l}\text { C. diffusa, E. grisebachii, P. paspaloides, } \\
\text { C. eragrostis, M. aquaticum }\end{array}$ \\
\hline E. grisebachii & L. hexandra & E. grisebachii & $\begin{array}{c}\text { L. hexandra, E. grisebachii, F. miliacea, } \\
\text { E. crusgalli, P. repens }\end{array}$ \\
\hline
\end{tabular}

$M$. aquaticum, $P$. australis and $A$. donax all continued to maintain a single dominant community. The advantages of $P$. cordata, A. calamus, $C$. esculenta and $C$. glauca in a partial single dominant community were replaced by the invasive species $A$. philoxeroides, $W$. trilobata and B. pilosa var. radiata. The advantages of $E$. grisebachii in a partial single dominant community were replaced by $L$. hexandra or $C$. diffusa. In addition, the community tracking survey also showed that the original single optimal $P$. cordata community and E. grisebachii community was also infiltrated by the exotic plants $M$. aquaticum and $H$. vulgaris.

\section{Discussion}

\subsection{Increase in Emergent Plant Richness Contributes to Species Richness Increases during Wetland Restoration/Construction}

Much research shows that the aquatic plant richness of the natural wetlands was increased, such as farmland wetlands in north-west Poland [31], Changhu Lake [32] [33], Lashi Lake [34] [35], and Napa Lake [23]; there are also reports of emergent plant coverage and wetland plant richness increases in restoration wetlands [36], while our study indicates that the major contributors to the increase in species richness during wetland restoration are emergent, particularly in those wetlands that have been restored for years. In these study wetlands, the ratio of emergent plants to total wetland plants is high, and the richness of emergent plants increases the most; the composition changes in submergent, floating and floating leaf plants in the total wetland plant figures is small, and the richness changes are also smaller. 


\subsection{The Species Spreading from Surrounding Wetlands Contributed to the Target Wetland Restoration and Reconstruction}

The aquatic plant germplasm resources of the target wetland were mainly sourced from surrounding wetlands. In 2013, there were only 23 species of emergent plants in Baiyun Lake, and this dramatically increased to 59 species in 2016. When the wetlands had just been built, most of the emergent plants may have come from the original soil seed bank, in general, and after the environment changes and most of the original species are cleared, those plants whose seeds are pre-existing in the seed bank are rapidly recruited [37] [38]. After several years, few new species still come from the original soil seed bank because only fresh seeds can greatly increase the possibility of a species settling [39]; thus, we believe that most of the new increases in species numbers between 2013 and 2016 mainly come from the distribution of surrounding wetlands. In addition, during Baiyun Lake's wetland plant community restoration process, wetland plant community composition and structure becomes more similar to the surrounding wetlands gradually over time. The closer to the wetland, the higher similarity of species composition; in particular, the Liuxi River wetland, which has river-lake connectivity with Baiyun Lake, has the highest similarity with Baiyun Lake. The result is confirmation that the plant communities in created marshes will become similar to those in the natural marshes, taking only a few years [25]. This also indicates that newly increasing plant species in Baiyun Lake may come from surrounding wetlands. The wetlands around Baiyun Lake have many more emergent plants, aside from the other three types of aquatic plants. This leads to the richness and abundance of emergent plant germplasm that enters in Baiyun Lake, more than the other three life forms of aquatic plants.

\subsection{The Restoration of Wetland Vegetation Should Give More Priority to the Submergent Plants}

Rational utilization of self-design and biological engineering in wetland restoration/construction needs to differentiate between emergent plants and submergent, floating and floating leaf plants. For Caohai Lake, during the self-design of wetland vegetation, the richness of emergent plants was increasing, but the richness of submergent, floating and floating leaf plants changed less. Referring to Baiyun Lake, the low abundance of the submergent plant species and germplasm resources in the surrounding wetland limited the submergent plants' spontaneous recovery in Baiyun Lake: no submergent plants were spreaded naturally in last 6 years, these results confirmed that species dispersal determine the number of species of submergent plants in restored wetlands [40], also confirmed that the need of submergent plant germplasm's introduction during the Baiyun Lake restoration. So, the input of submergent germplasm resources was increased in April 2016, including V. natans, H. verticillata, P. wrightii, M. spicatum and C. demersum. 


\subsection{Invasive Plants Will Seriously Affect the Restoration of Aquatic-Terrestrial Ecotone and Their Control Needs Human Intervention}

The restoration of wetlands requires the re-establishment of a native wetland plant community [41], where invasive species may cause unexpected changes [42] or dramatic ecological disturbances [9] because they have the ability to exclude other plant species [38]. The aquatic-terrestrial ecotone is vulnerable to invasive plants, and numerous invasive plants can harm this area. In Baiyun Lake's aquatic-terrestrial ecotone, A. philoxeroides, B. pilosa var. radiata, $W$. trilobata and other invasive plants spread faster and excluded other plant species, greatly influencing the regional vegetation restoration. In addition, the introduction of $M$. aquaticum and $H$. vulgaris have a potential risk of invasion [43] [44]. Therefore, implementing restoration/construction of wetland is needed to prevent invasive plant hazards to the aquatic-terrestrial ecotone.

\section{Conclusion}

The study confirms that before implementing wetland restoration/creation, pre-restoration surveys are required to the target wetland and its surrounding wetland. The study also finds that in Guangdong province, China, the restoration of wetland vegetation should give more priority to the submergent plants. Generally emergent plants community's invasive preventing and submergent plants germplasm resources introducing will be the focus of the human intervention in wetland restoration/creation.

\section{Acknowledgements}

The authors acknowledge Zijian Luo, Xingde Xiong, Master Quanlong Zhuo and Doctor Jiangang Zhao for their assistance in the collection of field data.

\section{Funding}

Funding was provided by the National Natural Science Foundation of China (Grant number: 31560107), the Science and Technology Program of Guangzhou, China (Grant number: 201508020104) and the Jinan University Postdoctoral Fund (Grant number: 55350053).

\section{Conflicts of Interest}

The authors declare no conflicts of interest regarding the publication of this paper.

\section{References}

[1] Mitsch, W.J., Wu, X., Nairn, R.W., Weihe, P.E., Wang, N., Deal, R. and Boucher, C.E. (1998) Creating and Restoring Wetlands: A Whole-Ecosystem Experiment in Self-Design. Bioscience, 48, 1019-1030. https://doi.org/10.2307/1313458

[2] van der Valk, A. (2016) Self-Design vs Designer Theories and Wetland Restoration 
and Creation. In: Finlayson, C.M., Everard, M., Irvine, K., McInnes, R.J., Middleton, B., van Dam, A. and Davidson, N.C., Eds., The Wetland Book: I: Structure and Function, Management and Methods, Springer, Netherlands, 1-4. https://doi.org/10.1007/978-94-007-6172-8_8-2

[3] Mitsch, W.J. and Wilson, R.F. (1996) Improving the Success of Wetland Creation and Restoration with Know-How, Time, and Self-Design. Ecological Applications, 6, 77-83. https://doi.org/10.2307/2269554

[4] Metzker, K.D. and Mitsch, W.J. (1997) Modelling Self-Design of the Aquatic Community in a Newly Created Freshwater Wetland. Ecological Modelling, 100, 61-86. https://doi.org/10.1016/S0304-3800(97)00157-9

[5] Malakoff, D. (1998) Restored Wetlands Flunk Real-World Test. Science, 280, 371-372. https://doi.org/10.1126/science.280.5362.371

[6] Mitsch, W.J., Zhang, L., Stefanik, K.C., Nahlik, A.M., Anderson, C.J., Bernal, B., Hernandez, M. and Song, K. (2012) Creating Wetlands: Primary Succession, Water Quality Changes, and Self-Design over 15 Years. Bioscience, 62, 237-250. https://doi.org/10.1525/bio.2012.62.3.5

[7] Young, P. (1996) The "New Science" of Wetland Restoration. Environmental Science \& Technology, 30, 292-296. https://doi.org/10.1021/es962317y

[8] Kellogg, C.H. and Bridgham, S.D. (2002) Colonization during Early Succession of Restored Freshwater Marshes. Canadian Journal of Botany-Revue Canadienne De Botanique, 80, 176-185. https://doi.org/10.1139/b02-001

[9] Mitsch, W.J., Lefeuvre, J.C. and Bouchard, V. (2002) Ecological Engineering Applied to River and Wetland Restoration. Ecological Engineering, 18, 529-541. https://doi.org/10.1016/S0925-8574(02)00018-6

[10] Zedler, J.B. (2000) Progress in Wetland Restoration Ecology. Trends in Ecology \& Evolution, 15, 402-407. https://doi.org/10.1016/S0169-5347(00)01959-5

[11] Kendrick, G.A., Waycott, M., Carruthers, T.J.B., Cambridge, M.L., Hovey, R., Krauss, S.L., Lavery, P.S., Les, D.H., Lowe, R.J., Vidal, O.M., Ooi, J.L.S., Orth, R.J., Rivers, D.O., Ruiz-Montoya, L., Sinclair, E.A., Statton, J., van Dijk, J.K. and Verduin, J.J. (2012) The Central Role of Dispersal in the Maintenance and Persistence of Seagrass Populations. BioScience, 62, 56-65.

https://doi.org/10.1525/bio.2012.62.1.10

[12] Berkovic, B., Cabaco, S., Barrio, J.M., Rui, S., Serrão, E.A. and Alberto, F. (2014) Extending the Life History of a Clonal Aquatic Plant: Dispersal Potential of Sexual and Asexual Propagules of Zostera noltii. Aquatic Botany, 113, 123-129. https://doi.org/10.1016/j.aquabot.2013.10.007

[13] Darwin, C.R. (1859) On the Origin of Species by Means of Natural Selection, or the Preservation of Favoured Races in the Struggle for Life. John Murray, London.

[14] Barrat-Segretain, M.H. (1996) Strategies of Reproduction, Dispersion, and Competition in River Plants: A Review. Vegetatio, 123, 13-37. https://doi.org/10.1007/BF00044885

[15] Raulings, E., Morris, K.A.Y., Thompson, R. and Nally, R.M. (2011) Do Birds of a Feather Disperse Plants Together? Freshwater Biology, 56, 1390-1402. https://doi.org/10.1111/j.1365-2427.2011.02576.x

[16] Pollux, B.J., Jong, M.D., Steegh, A., Verbruggen, E., van Groenendael, J.M. and Ouborg, N.J. (2007) Reproductive Strategy, Clonal Structure and Genetic Diversity in Populations of the Aquatic Macrophyte Sparganium emersum in River Systems. Molecular Ecology, 16, 313-325. https://doi.org/10.1111/j.1365-294X.2006.03146.x 
[17] Nilsson, C., Brown, R.L., Jansson, R. and Merritt, D.M. (2010) The Role of Hydrochory in Structuring Riparian and Wetland Vegetation. Biological Reviews, 85, 837-858.

[18] Li, W. (2014) Environmental Opportunities and Constraints in the Reproduction and Dispersal of Aquatic Plants. Aquatic Botany, 118, 62-70.

https://doi.org/10.1016/j.aquabot.2014.07.008

[19] Smulders, M.J.M., Cottrell, J.E., Lefèvre, F., Schoot, J.V.D., Arens, P., Vosman, B., et al. (2008) Structure of the Genetic Diversity in Black Poplar (Populus nigra L.) Populations across European River Systems: Consequences for Conservation and Restoration. Forest Ecology and Management, 255, 1388-1399. https://doi.org/10.1016/j.foreco.2007.10.063

[20] Santamaria, L. (2002) Why Are Most Aquatic Plants Widely Distributed? Dispersal, Clonal Growth and Small-Scale Heterogeneity in a Stressful Environment. Acta Oecologica-International Journal of Ecology, 23, 137-154. https://doi.org/10.1016/S1146-609X(02)01146-3

[21] Seabloom, E.W. and van der Valk, A.G. (2003) Plant Diversity, Composition, and Invasion of Restored and Natural Prairie Pothole Wetlands: Implications for Restoration. Wetlands, 23, 1-12. https://doi.org/10.1672/0277-5212(2003)023[0001:PDCAIO]2.0.CO;2

[22] Anderson, K.J. (2007) Temporal Patterns in Rates of Community Change during Succession. The American Naturalist, 169, 780-793. https://doi.org/10.1086/516653

[23] Liu, G.D., Tian, K., Sun, J., Xiao, D. and Yuan, X. (2016) Evaluating the Effects of Wetland Restoration at the Watershed Scale in Northwest Yunnan Plateau, China. Wetlands, 36, 169-183. https://doi.org/10.1007/s13157-015-0727-2

[24] Mitsch, W.J., Zhang, L., Anderson, C.J., Altor, A.E. and Hernández, M.E. (2005) Creating Riverine Wetlands: Ecological Succession, Nutrient Retention, and Pulsing Effects. Ecological Engineering, 25, 510-527. https://doi.org/10.1016/j.ecoleng.2005.04.014

[25] Edwards, K.R. and Proffitt, C.E. (2003) Comparison of Wetland Structural Characteristics between Created and Natural Salt Marshes in Southwest Louisiana, USA. Wetlands, 23, 344-356. https://doi.org/10.1672/10-20

[26] Sculthorpe, C.D. (1967) The Biology of Aquatic Vascular Plants. St. Martin's Press, New York.

[27] Yuan, J.M. (1986) Research on Aquatic Vegetation and Biomass of Caohai Lake. In: Institute of Biology, Guizhou Academy of Sciences, Eds., Report on Scientific Investigation of Caohai Lake, Guizhou People's Press, Guiyang, 134-145.

[28] Chen, X., Xia, Y.P., Li, Q., et al. (2007) Study on the Change of Aquatic Vegetation and Biomass in the National Nature Reserve of Caohai Lake. In: Zhang, H.H., Li, M.J. and Yao, S.L., Eds., Caohai Lake Research, Guizhou Cience and Technology Press, Guiyang, 141.

[29] Liu, W., Li, H., Zhang, Y.W. and Yuan, G. (2015) Distribution Status and Changes in Recent 30 Years of Aquatic Vascular Plants in Caohai of Guizhou. Hubei Agricultural Sciences, 54, 5872-5876.

[30] Jaccard, P. (1912) The Distribution of the Flora in the Alpine Zone. The New Phytologist, 11, 37-50. http://www.jstor.org/stable/2427226 https://doi.org/10.1111/j.1469-8137.1912.tb05611.x

[31] Goldyn, H. (2010) Changes in Plant Species Diversity of Aquatic Ecosystems in the Agricultural Landscape in West Poland in the Last 30 Years. Biodiversity and Conservation, 19, 61-80. https://doi.org/10.1007/s10531-009-9702-7 
[32] Feng, C., Wang, X.L., Wang, Z.X. and Ban, J.D. (1989) Studies on the Communities of Aquatic Vascular Plant in Changhu Lake. Journal of Wuhan Botanical Research, 7, 123-130.

[33] Hao, M.X., Yang, L., Kong, X.H., Xu, X., Lu, W. and Li, Z.Q. (2015) Diversity and Community Succession of Macrophytes in Lake Changhu, Hubei Province. Journal of Lake Sciences, 27, 94-102. https://doi.org/10.18307/2015.0112

[34] Yang, B. (2003) The Biodiversity of the Lashi Lake. Guangdong Forestry Surveying \& Designing, 2, 11-17.

[35] Hu, Y.Y. (2008) Study on Distribution Pattern of Wetland Community and Plant Diversity of Lashi Lake, Li Jiang. Southwest Forestry University.

[36] Moore, H.H., Niering, W.A., Marsicano, L.J. and Dowdell, M. (1999) Vegetation Change in Created Emergent Wetlands (1988-1996) in Connecticut (USA). Wetlands Ecology \& Management, 7, 177-191. https://doi.org/10.1023/A:1008434630473

[37] van der Valk, A.G., Pederson, R.L. and Davis, C.B. (1992) Restoration and Creation of Freshwater Wetlands Using Seed Banks. Wetlands Ecology \& Management, 1, 191-197. https://doi.org/10.1007/BF00244924

[38] Ailstock, M.S., Norman, C.M. and Bushmann, P.J. (2001) Common Reed Phragmites australis: Control and Effects upon Biodiversity in Freshwater Nontidal Wetlands. Restoration Ecology, 9, 49-59.

https://doi.org/10.1046/j.1526-100x.2001.009001049.x

[39] van der Valk, A.G., Bremholm, T.L. and Gordon, E. (1999) The Restoration of Sedge Meadows: Seed Viability, Seed Germination Requirements, and Seedling Growth of Carex Species. Wetlands, 19, 756-764. https://doi.org/10.1007/BF03161782

[40] Brown, S.C. and Bedford, B.L. (1997) Restoration of Wetland Vegetation with Transplanted Wetland Soil: An Experimental Study. Wetlands, 17, 424-437. https://doi.org/10.1007/BF03161432

[41] Akasaka, M. and Takamura, N. (2011) The Relative Importance of Dispersal and the Local Environment for Species Richness in Two Aquatic Plant Growth Forms. Oikos, 120, 38-46. https://doi.org/10.1111/j.1600-0706.2010.18497.x

[42] Klötzli, F. and Grootjans, A.P. (2010) Restoration of Natural and Semi-Natural Wetland Systems in Central Europe: Progress and Predictability of Developments. Restoration Ecology, 9, 209-219. https://doi.org/10.1046/j.1526-100x.2001.009002209.x

[43] Hussner, A. (2009) Growth and Photosynthesis of Four Invasive Aquatic Plant Species in Europe. Weed Research, 49, 506-515. https://doi.org/10.1111/j.1365-3180.2009.00721.x

[44] Miao, L.H., Ji, M.C., Wang, Y.Y., Qiao, D.D. and Chen, Y.C. (2011) Study on Invasion Risk of Hydroeotyle vulgaris as an Alien Species in Wetlands. Journal of Zhejiang University, 37, 425-431. 


\section{Appendix}

Table S1. The vegetation data of Caohai Lake from 1985 to 2016. EP: Emergent plants, SP: Submergent plants, FP: Floating plants, FLP: Floating leaf plants. “+” marked species are record species in the surveys.

\begin{tabular}{|c|c|c|c|c|c|c|c|}
\hline Life form & Species & Family & Genus & 1985 & 2005 & 2013 & $2015-2016$ \\
\hline EP & Sagittaria sagittifolia & Alismataceae & Sagittaria & + & + & + & + \\
\hline EP & Alisma plantago-aquatica & Alismataceae & Alisma & + & + & + & + \\
\hline EP & Scirpus triqueter & Cyperaceae & Scirpus & + & + & + & + \\
\hline $\mathrm{EP}$ & Scirpus tabernaemontani & Cyperaceae & Scirpus & + & + & + & + \\
\hline $\mathrm{EP}$ & Juncellus serotinus & Cyperaceae & Juncellus & + & + & + & + \\
\hline EP & Scirpus triangulates & Cyperaceae & Scirpus & + & + & + & + \\
\hline $\mathrm{EP}$ & Scirpus yagara & Cyperaceae & Scirpus & + & + & + & + \\
\hline $\mathrm{EP}$ & Eleocharis sp. & Cyperaceae & Eleocharis & + & + & + & + \\
\hline $\mathrm{EP}$ & Zizania latifolia & Gramineae & Zizania & + & + & + & + \\
\hline $\mathrm{EP}$ & Acorus calamus & Araceae & Acorus & + & + & + & + \\
\hline EP & Leersia hexandra & Gramineae & Leersia & + & + & + & + \\
\hline $\mathrm{EP}$ & Epilobium hirsutum & Onagraceae & Epilobium & + & + & + & + \\
\hline $\mathrm{EP}$ & Rumex nepalensis & Polygonaceae & Rumex & + & + & + & + \\
\hline $\mathrm{EP}$ & Oenanthe javanica & Umbelliferae & Oenanthe & + & + & + & + \\
\hline $\mathrm{EP}$ & Commelina diffusa & Equisetaceae & Equisetum & + & + & + & + \\
\hline EP & Echinochloa crusgalli & Gramineae & Echinochloa & + & + & + & + \\
\hline $\mathrm{EP}$ & Juncus effusus & Juncaceae & Juncus & + & + & + & + \\
\hline $\mathrm{EP}$ & Polygonum lapathifolium & Polygonaceae & Polygonum & + & + & + & + \\
\hline EP & Ranunculus sceleratus & Ranunculaceae & Ranunculus & + & + & + & + \\
\hline FP & Spirodela polyrhiza & Lemnaceae & Spirodela & + & + & + & + \\
\hline FLP & Marsilea quadrifolia & Marsileaceae & Marsilea & + & + & + & + \\
\hline FLP & Nymphoides peltatum & Menyanthaceae & Nymphoides & + & + & + & + \\
\hline FLP & Potamogeton distinctus & Potamogetonaceae & Potamogeton & + & + & + & + \\
\hline FLP & Polygonum amphibium & Polygonaceae & Polygonum & + & + & + & + \\
\hline SP & $\begin{array}{l}\text { Ceratophyllum platyacanthum } \\
\text { subsp. oryzetorum }\end{array}$ & Ceratophyllaceae & Ceratophyllum & + & + & + & + \\
\hline SP & Potamogeton lucens & Potamogetonaceae & Potamogeton & + & + & + & + \\
\hline SP & Potamogeton maackianus & Potamogetonaceae & Potamogeton & + & + & + & + \\
\hline SP & Potamogeton pectinatus & Potamogetonaceae & Potamogeton & + & + & + & + \\
\hline SP & Potamogeton perfoliatus & Potamogetonaceae & Potamogeton & + & + & + & + \\
\hline SP & Potamogeton malaianus & Potamogetonaceae & Potamogeton & + & + & + & + \\
\hline SP & Potamogeton crispus & Potamogetonaceae & Potamogeton & + & + & + & + \\
\hline SP & Nitella mucosa & Characeae & Nitella & + & + & + & + \\
\hline SP & Nitellopsis obtusa & Characeae & Nitellopsis & + & + & + & + \\
\hline SP & Chara vulgaris & Characeae & Chara & + & + & + & + \\
\hline SP & Myriophyllum spicatum & Haloragidaceae & Myriophyllum & + & + & + & + \\
\hline
\end{tabular}




\section{Continued}

\begin{tabular}{|c|c|c|c|c|c|c|c|}
\hline SP & Hydrilla verticillata & Hydrocharitaceae & Hydrilla & + & + & + & + \\
\hline SP & Ottelia acuminata & Hydrocharitaceae & Ottelia & + & + & + & + \\
\hline SP & Utricularia aurea & Lentibulariaceae & Utricularia & + & + & + & + \\
\hline SP & Najas marina & Najadaceae & Najas & + & + & + & + \\
\hline SP & Najas minor & Najadaceae & Najas & + & + & + & + \\
\hline FLP & Trapa natans & Trapaceae & Trapa & + & + & + & \\
\hline $\mathrm{EP}$ & Alternanthera sessilis & Amaranthaceae & Alternanthera & & + & + & + \\
\hline $\mathrm{EP}$ & Kalimeris indica & Compositae & Kalimeris & & + & + & + \\
\hline $\mathrm{EP}$ & Taraxacum mongolicum & Compositae & Taraxacum & & + & + & + \\
\hline $\mathrm{EP}$ & Trifolium repens & Leguminosae & Trifolium & & + & + & + \\
\hline $\mathrm{EP}$ & Verbena officinalis & Verbenaceae & Verbena & & + & + & + \\
\hline $\mathrm{EP}$ & Conyza canadensis & Compositae & Conyza & & + & + & + \\
\hline $\mathrm{EP}$ & Polygonum hydropiper & Polygonaceae & Polygonum & & + & + & + \\
\hline FP & Lemna minor & Lemnaceae & Lemna & & + & + & + \\
\hline FP & Azolla imbricata & Azollaceae & Azolla & & + & + & \\
\hline $\mathrm{EP}$ & Dichrocephala benthamii & Compositae & Dichrocephala & & + & & \\
\hline $\mathrm{EP}$ & Xanthium sibiricum & Compositae & Xanthium & & + & & \\
\hline $\mathrm{EP}$ & Equisetum ramosissimum & Equisetaceae & Equisetum & & & + & + \\
\hline $\mathrm{EP}$ & Phragmites australis & Gramineae & Phragmites & & & + & + \\
\hline $\mathrm{EP}$ & Typha angustifolia & Typhaceae & Typha & & & + & + \\
\hline $\mathrm{EP}$ & Iris tectorum & Iridaceae & Iris & & & + & + \\
\hline $\mathrm{EP}$ & Rumex japonicus & Polygonaceae & Rumex & & & + & + \\
\hline $\mathrm{EP}$ & Sparganium stoloniferum & Sparganiaceae & Sparganium & & & + & + \\
\hline $\mathrm{EP}$ & Rumex dentatus & Polygonaceae & Rumex & & & + & + \\
\hline $\mathrm{EP}$ & Polygonum lapathifolium var. salicifolium & Polygonaceae & Polygonum & & & + & + \\
\hline SP & Potamogeton pusillus & Potamogetonaceae & Potamogeton & & & + & + \\
\hline $\mathrm{EP}$ & Carex cruciata & Cyperaceae & Carex & & & + & \\
\hline $\mathrm{EP}$ & Lythrum salicaria & Lythraceae & Lythrum & & & + & \\
\hline $\mathrm{EP}$ & Houttuynia cordata & Saururaceae & Houttuynia & & & + & \\
\hline $\mathrm{EP}$ & Hydrocotyle sibthorpioides & Umbelliferae & Hydrocotyle & & & + & \\
\hline $\mathrm{EP}$ & Mariscus umbellatus & Cyperaceae & Mariscus & & & + & \\
\hline $\mathrm{EP}$ & Carex heterolepis & Cyperaceae & Carex & & & & + \\
\hline $\mathrm{EP}$ & Artemisia selengensis & Compositae & Artemisia & & & & + \\
\hline $\mathrm{EP}$ & Paspalum paspaloides & Gramineae & Paspalum & & & & + \\
\hline $\mathrm{EP}$ & Catabrosa aquatica & Gramineae & Catabrosa & & & & + \\
\hline $\mathrm{EP}$ & Cynodon dactylon & Gramineae & Cynodon & & & & + \\
\hline $\mathrm{EP}$ & Rumex crispus & Polygonaceae & Rumex & & & & + \\
\hline
\end{tabular}




\section{Continued}

\begin{tabular}{|c|c|c|c|c|}
\hline EP & Ranunculus japonicus & Ranunculaceae & Ranunculus & + \\
\hline EP & Oenanthe linearis subsp. Rivularis & Umbelliferae & Oenanthe & + \\
\hline EP & Galinsoga parviflora & Compositae & Galinsoga & + \\
\hline EP & Rorippa islandica & Cruciferae & Rorippa & + \\
\hline $\mathrm{EP}$ & Rorippa indica & Cruciferae & Rorippa & + \\
\hline EP & Beckmannia syzigachne & Gramineae & Beckmannia & + \\
\hline EP & Polypogon fugax & Gramineae & Polypogon & + \\
\hline EP & Juncus prismatocarpus & Juncaceae & Juncus & + \\
\hline $\mathrm{EP}$ & Plantago asiatica & Plantaginaceae & Plantago & + \\
\hline $\mathrm{EP}$ & Polygonum nepalense & Polygonaceae & Polygonum & + \\
\hline EP & Polygonum longisetum var. rotundatum & Polygonaceae & Polygonum & + \\
\hline EP & Polygonum viscosum & Polygonaceae & Polygonum & + \\
\hline $\mathrm{EP}$ & Ranunculus chinensis Bunge & Ranunculaceae & Ranunculus & + \\
\hline $\mathrm{EP}$ & Ranunculus cantoniensis & Ranunculaceae & Ranunculus & + \\
\hline $\mathrm{EP}$ & Mazus japonicus & Scrophulariaceae & Mazus & + \\
\hline FP & Ricciocarpus natans & Ricciaceae & Ricciocarpus & + \\
\hline
\end{tabular}

Table S2. The line-intercept survey result of Baiyun Lake and 8 surrounding wetlands. EP: Emergent plants, SP: Submergent plants, FP: Floating plants, FLP: Floating leaf plants. TF: Total Frequency, the sum of the frequency of the species in the 8 wetlands, TA: Total abundance, the sum of the abundance of the species in the 8 wetlands. ${ }^{*}$ marked species are introduced before 2013, "marked species are introduced in 2016. Species abundance classification quantification as $5,4,3,2$, 1, and 0 ; for species cultivated in Baiyun Lake but not seen in the surrounding wetland, their abundance is recorded as "/".

\begin{tabular}{|c|c|c|c|c|c|c|c|c|c|c|c|c|c|c|c|c|}
\hline Origin & Life form & Family & Genus & Spices & B13 & $\mathrm{B} 16$ & LX & LG & DS & $\mathrm{TL}$ & ZJ & WJ & $\mathrm{HJ}$ & DJ & $T F$ & $T A$ \\
\hline Native & SP & Hydrocharitaceae & Vallisneria & ${ }^{*}$ Vallisneria natans & 4 & 5 & 4 & 3 & 0 & 0 & 0 & 3 & 5 & 0 & 4 & 15 \\
\hline Native & SP & Hydrocharitaceae & Hydrilla & ${ }^{*} H y d r i l l a$ verticillata & 0 & 5 & 4 & 0 & 0 & 0 & 0 & 4 & 3 & 4 & 4 & 15 \\
\hline Native & SP & Potamogetonaceae & Potamogeton & ${ }^{\#}$ Potamogeton wrightii & 0 & 3 & 4 & 0 & 0 & 0 & 0 & 5 & 1 & 0 & 3 & 10 \\
\hline Native & SP & Potamogetonaceae & Potamogeton & Potamogeton crispus & 0 & 0 & 3 & 3 & 0 & 0 & 0 & 2 & 0 & 1 & 4 & 9 \\
\hline Native & SP & Characeae & Chara & Chara vulgaris & 0 & 0 & 0 & 0 & 0 & 0 & 0 & 3 & 0 & 2 & 2 & 5 \\
\hline Native & SP & Haloragaceae & Myriophyllum & ${ }^{\#}$ Myriophyllum spicatum & 0 & 2 & 0 & 0 & 0 & 0 & 0 & 2 & 1 & 0 & 2 & 3 \\
\hline Native & SP & Ceratophyllaceae & Ceratophyllum & ${ }^{\sharp}$ Ceratophyllum demersum & 0 & 2 & 0 & 0 & 0 & 0 & 0 & 1 & 1 & 0 & 2 & 2 \\
\hline Native & SP & Najadaceae & Najas & Najas graminea & 0 & 0 & 0 & 0 & 0 & 0 & 1 & 0 & 0 & 0 & 1 & 1 \\
\hline Native & FP & Lemnaceae & Lemna & Lemna minor & 0 & 2 & 0 & 0 & 0 & 0 & 3 & 3 & 0 & 2 & 3 & 8 \\
\hline Native & FP & Lemnaceae & Spirodela & Spirodela polyrhiza & 0 & 0 & 0 & 0 & 0 & 0 & 0 & 3 & 0 & 2 & 2 & 5 \\
\hline Native & FP & Azollaceae & Azolla & Azolla imbricata & 0 & 0 & 0 & 0 & 0 & 0 & 0 & 0 & 0 & 5 & 1 & 5 \\
\hline Native & FLP & Trapaceae & Trapa & ${ }^{*}$ Trapa incisa & 0 & 1 & I & I & I & I & I & I & I & I & l & l \\
\hline Native & FLP & Hydrocharitaceae & Hydrocharis & ${ }^{\#}$ Hydrocharis dubia & 0 & 1 & I & I & I & I & I & I & I & I & I & I \\
\hline Native & FLP & Onagraceae & Ludwigia & ${ }^{\star}$ Ludwigia adscendens & 5 & 5 & 0 & 3 & 1 & 0 & 0 & 0 & 0 & 2 & 3 & 6 \\
\hline Native & FLP & Nelumbonaceae & Nelumbo & ${ }^{*}$ Nelumbo nucifera & 5 & 5 & 0 & 0 & 1 & 0 & 0 & 0 & 0 & 0 & 1 & 4 \\
\hline Native & FLP & Marsileaceae & Marsilea & Marsilea minuta & 0 & 0 & 0 & 0 & 0 & 0 & 0 & 3 & 0 & 0 & 1 & 3 \\
\hline
\end{tabular}




\section{Continued}

\begin{tabular}{|c|c|c|c|c|c|c|c|c|c|c|c|c|c|c|c|c|}
\hline Native & $\mathrm{EP}$ & Typhaceae & Typha & ${ }^{*}$ Typha angustifolia & 3 & 3 & I & l & l & / & l & I & I & I & l & l \\
\hline Native & $\mathrm{EP}$ & Cyperaceae & Schoenoplectus & $\begin{array}{l}{ }^{*} \text { Schoenoplectus } \\
\text { tabernaemontani }\end{array}$ & 4 & 3 & / & I & l & l & I & 1 & I & I & / & l \\
\hline Native & $\mathrm{EP}$ & Juncaceae & Juncus & ${ }^{\star} J$ uncus effusus & 3 & 2 & I & I & l & I & I & I & I & I & l & l \\
\hline Native & $\mathrm{EP}$ & Iridaceae & Iris & ${ }^{*}$ Iris ensata var. hortensis & 4 & 4 & / & l & l & l & l & l & / & / & / & l \\
\hline Native & $\mathrm{EP}$ & Poaceae & Arundo & $\begin{array}{l}\text { *Arundo donax } \\
\text { "Versicolor" }\end{array}$ & 4 & 4 & / & l & l & l & l & I & I & I & / & l \\
\hline Native & $\mathrm{EP}$ & Alismataceae & Alisma & *Alisma canaliculatum & 4 & 4 & I & I & l & I & l & I & l & l & l & l \\
\hline Native & $\mathrm{EP}$ & Commelinaceae & Commelina & Commelina communis & 4 & 5 & 5 & 5 & 5 & 5 & 4 & 4 & 4 & 5 & 8 & 37 \\
\hline Native & $\mathrm{EP}$ & Polygonaceae & Polygonum & Polygonum lapathifolium & 0 & 2 & 5 & 4 & 3 & 3 & 3 & 3 & 4 & 4 & 8 & 29 \\
\hline Native & $\mathrm{EP}$ & Poaceae & Paspalum & Paspalum paspaloides & 3 & 4 & 5 & 3 & 0 & 0 & 4 & 5 & 5 & 5 & 6 & 27 \\
\hline Native & $\mathrm{EP}$ & Poaceae & Leersia & Leersia hexandra & 4 & 5 & 5 & 3 & 5 & 4 & 5 & 0 & 0 & 5 & 6 & 27 \\
\hline Native & $\mathrm{EP}$ & Araceae & Colocasia & ${ }^{*}$ Colocasia esculenta & 4 & 4 & 4 & 4 & 3 & 3 & 3 & 3 & 2 & 3 & 8 & 25 \\
\hline Native & $\mathrm{EP}$ & Polygonaceae & Polygonum & Polygonum chinense & 0 & 0 & 5 & 0 & 5 & 0 & 4 & 0 & 2 & 4 & 5 & 20 \\
\hline Native & $\mathrm{EP}$ & Poaceae & Arundo & ${ }^{*}$ Arundo donax & 3 & 3 & 4 & 4 & 3 & 1 & 0 & 2 & 4 & 0 & 6 & 18 \\
\hline Native & $\mathrm{EP}$ & Poaceae & Panicum & Panicum repens & 4 & 4 & 4 & 0 & 4 & 4 & 0 & 2 & 0 & 0 & 4 & 14 \\
\hline Native & $\mathrm{EP}$ & Asteraceae & Eclipta & Eclipta prostrata & 2 & 3 & 2 & 2 & 2 & 1 & 2 & 2 & 2 & 0 & 7 & 13 \\
\hline Native & $\mathrm{EP}$ & Poaceae & Echinochloa & Echinochloa crusgalli & 0 & 2 & 3 & 2 & 2 & 2 & 0 & 2 & 2 & 0 & 6 & 13 \\
\hline Native & $\mathrm{EP}$ & Amaranthaceae & Alternanthera & Alternanthera sessilis & 0 & 3 & 2 & 2 & 2 & 3 & 0 & 3 & 1 & 0 & 6 & 13 \\
\hline Native & $\mathrm{EP}$ & Poaceae & Neyraudia & Neyraudia reynaudiana & 0 & 0 & 4 & 0 & 0 & 3 & 3 & 0 & 0 & 3 & 4 & 13 \\
\hline Native & $\mathrm{EP}$ & Poaceae & Phragmites & ${ }^{\star}$ Phragmites australis & 3 & 3 & 5 & 4 & 0 & 0 & 0 & 0 & 4 & 0 & 3 & 13 \\
\hline Native & $\mathrm{EP}$ & Onagraceae & Ludwigia & Ludwigia hyssopifolia & 0 & 2 & 2 & 2 & 2 & 0 & 4 & 2 & 0 & 0 & 5 & 12 \\
\hline Native & $\mathrm{EP}$ & Polygonaceae & Rumex & Rumex trisetifer & 3 & 3 & 2 & 2 & 2 & 3 & 0 & 0 & 0 & 1 & 5 & 10 \\
\hline Native & $\mathrm{EP}$ & Cyperaceae & Cyperus & Cyperus iria & 0 & 2 & 2 & 1 & 1 & 1 & 1 & 2 & 1 & 0 & 7 & 9 \\
\hline Native & $\mathrm{EP}$ & Scrophulariaceae & Lindernia & Lindernia procumbens & 0 & 3 & 2 & 0 & 2 & 0 & 0 & 3 & 2 & 0 & 4 & 9 \\
\hline Native & $\mathrm{EP}$ & Cyperaceae & Kyllinga & Kyllinga polyphylla & 0 & 3 & 2 & 2 & 2 & 0 & 0 & 0 & 0 & 2 & 4 & 8 \\
\hline Native & $\mathrm{EP}$ & Cyperaceae & Fimbristylis & Fimbristylis littoralis & 0 & 1 & 1 & 0 & 1 & 0 & 3 & 3 & 0 & 0 & 4 & 8 \\
\hline Native & $\mathrm{EP}$ & Polygonaceae & Polygonum & Polygonum japonicum & 0 & 0 & 2 & 0 & 2 & 0 & 2 & 0 & 0 & 1 & 4 & 7 \\
\hline Native & $\mathrm{EP}$ & Pontederiaceae & Monochoria & Monochoria vaginalis & 0 & 1 & 1 & 0 & 0 & 0 & 3 & 3 & 0 & 0 & 3 & 7 \\
\hline Native & $\mathrm{EP}$ & Juglandaceae & Pterocarya & ${ }^{*}$ Pterocarya stenoptera & 1 & 1 & 0 & 0 & 0 & 0 & 0 & 3 & 4 & 0 & 2 & 7 \\
\hline Native & $\mathrm{EP}$ & Scrophulariaceae & Lindernia & Lindernia crustacea & 0 & 3 & 1 & 0 & 2 & 1 & 1 & 0 & 0 & 1 & 5 & 6 \\
\hline Native & $\mathrm{EP}$ & Cyperaceae & Eleocharis & Eleocharis sp. & 0 & 0 & 0 & 0 & 3 & 0 & 1 & 0 & 1 & 1 & 4 & 6 \\
\hline Native & $\mathrm{EP}$ & Cruciferae & Cardamine & Cardamine hirsuta & 2 & 3 & 2 & 2 & 0 & 1 & 1 & 0 & 0 & 0 & 4 & 6 \\
\hline Native & $\mathrm{EP}$ & Myrtaceae & Syzygium & Syzygium nervosum & 0 & 0 & 5 & 0 & 0 & 1 & 0 & 0 & 0 & 0 & 2 & 6 \\
\hline Native & $\mathrm{EP}$ & Commelinaceae & Floscopa & Floscopa scandens & 0 & 0 & 3 & 0 & 0 & 0 & 3 & 0 & 0 & 0 & 2 & 6 \\
\hline Native & $\mathrm{EP}$ & Araceae & Acorus & Acorus tatarinowii & 0 & 0 & 1 & 0 & 0 & 0 & 1 & 1 & 1 & 1 & 5 & 5 \\
\hline Native & $\mathrm{EP}$ & Polygonaceae & Polygonum & Polygonum hydropiper & 0 & 0 & 1 & 0 & 1 & 1 & 0 & 0 & 2 & 0 & 4 & 5 \\
\hline Native & $\mathrm{EP}$ & Equisetaceae & Equisetum & Equisetum ramosissimum & 0 & 0 & 2 & 0 & 0 & 0 & 1 & 1 & 1 & 0 & 4 & 5 \\
\hline
\end{tabular}




\section{Continued}

\begin{tabular}{|c|c|c|c|c|c|c|c|c|c|c|c|c|c|c|c|c|}
\hline Native & $\mathrm{EP}$ & Ranunculaceae & Ranunculus & Ranunculus sceleratus & 2 & 2 & 0 & 2 & 0 & 2 & 0 & 0 & 0 & 1 & 3 & 5 \\
\hline Native & $\mathrm{EP}$ & Onagraceae & Ludwigia & Ludwigia octovalvis & 0 & 1 & 1 & 0 & 2 & 2 & 0 & 0 & 0 & 0 & 3 & 5 \\
\hline Native & $\mathrm{EP}$ & Cyperaceae & Cyperus & Cyperus exaltatus & 0 & 0 & 0 & 1 & 1 & 3 & 0 & 0 & 0 & 0 & 3 & 5 \\
\hline Native & $\mathrm{EP}$ & Araceae & Alocasia & Alocasia cucullata & 3 & 3 & 1 & 2 & 0 & 2 & 0 & 0 & 0 & 0 & 3 & 5 \\
\hline Native & $\mathrm{EP}$ & Poaceae & Sesbania & Sesbania cannabina & 0 & 1 & 1 & 1 & 1 & 0 & 0 & 0 & 1 & 0 & 4 & 4 \\
\hline Native & $\mathrm{EP}$ & Polygonaceae & Polygonum & Polygonum perfoliatum & 0 & 0 & 0 & 0 & 1 & 1 & 1 & 0 & 0 & 1 & 4 & 4 \\
\hline Native & $\mathrm{EP}$ & Scrophulariaceae & Mazus & Mazus pumilus & 1 & 1 & 1 & 0 & 0 & 0 & 1 & 1 & 0 & 1 & 4 & 4 \\
\hline Native & $\mathrm{EP}$ & Juncaceae & Juncus & Juncus prismatocarpus & 0 & 1 & 1 & 0 & 1 & 0 & 1 & 0 & 0 & 1 & 4 & 4 \\
\hline Native & $\mathrm{EP}$ & Cyperaceae & Cyperus & Cyperus haspan & 0 & 1 & 0 & 0 & 1 & 1 & 1 & 0 & 0 & 1 & 4 & 4 \\
\hline Native & EP & Polygonaceae & Polygonum & $\begin{array}{l}\text { Polygonum longisetum } \\
\text { var. rotundatum }\end{array}$ & 0 & 2 & 2 & 1 & 0 & 0 & 0 & 1 & 0 & 0 & 3 & 4 \\
\hline Native & $\mathrm{EP}$ & Gentianaceae & Nymphoides & Ipomoea aquatica & 0 & 0 & 0 & 0 & 1 & 1 & 0 & 2 & 0 & 0 & 3 & 4 \\
\hline Native & $\mathrm{EP}$ & Poaceae & Zizania & Zizania latifolia & 0 & 0 & 0 & 0 & 0 & 0 & 2 & 2 & 0 & 0 & 2 & 4 \\
\hline Native & $\mathrm{EP}$ & Brassicaceae & Rorippa & Rorippa globosa & 2 & 2 & 2 & 2 & 0 & 0 & 0 & 0 & 0 & 0 & 2 & 4 \\
\hline Native & $\mathrm{EP}$ & Cyperaceae & Rhynchospora & Rhynchospora corymbosa & 0 & 0 & 1 & 0 & 3 & 0 & 0 & 0 & 0 & 0 & 2 & 4 \\
\hline Native & $\mathrm{EP}$ & Callitrichaceae & Callitriche & Callitriche palustris & 0 & 2 & 0 & 0 & 0 & 0 & 0 & 0 & 0 & 4 & 1 & 4 \\
\hline Native & $\mathrm{EP}$ & Cyperaceae & Schoenoplectus & $\begin{array}{c}\text { Schoenoplectus mucronatus } \\
\text { subsp. robustus }\end{array}$ & 0 & 0 & 0 & 0 & 4 & 0 & 0 & 0 & 0 & 0 & 1 & 4 \\
\hline Native & $\mathrm{EP}$ & Polygonaceae & Polygonum & Polygonum thunbergii & 0 & 0 & 0 & 0 & 0 & 0 & 4 & 0 & 0 & 0 & 1 & 4 \\
\hline Native & $\mathrm{EP}$ & Lythraceae & Rotala & Rotala indica & 0 & 0 & 0 & 0 & 0 & 0 & 1 & 1 & 0 & 1 & 3 & 3 \\
\hline Native & $\mathrm{EP}$ & Ranunculaceae & Ranunculus & Ranunculus cantoniensis & 0 & 0 & 1 & 0 & 0 & 1 & 0 & 0 & 0 & 1 & 3 & 3 \\
\hline Native & $\mathrm{EP}$ & Polygonaceae & Polygonum & Polygonum plebeium & 2 & 2 & 1 & 1 & 1 & 0 & 0 & 0 & 0 & 0 & 3 & 3 \\
\hline Native & $\mathrm{EP}$ & Cyperaceae & Cyperus & Cyperus difformis & 0 & 2 & 0 & 1 & 0 & 1 & 0 & 1 & 0 & 0 & 3 & 3 \\
\hline Native & $\mathrm{EP}$ & Rubiaceae & Adina & Adina rubella & 0 & 0 & 0 & 0 & 1 & 1 & 0 & 1 & 0 & 0 & 3 & 3 \\
\hline Native & $\mathrm{EP}$ & Polygonaceae & Polygonum & Polygonum pubescens & 0 & 0 & 2 & 0 & 0 & 0 & 1 & 0 & 0 & 0 & 2 & 3 \\
\hline Native & $\mathrm{EP}$ & Apiaceae & Oenanthe & Oenanthe javanica & 0 & 1 & 1 & 0 & 0 & 0 & 2 & 0 & 0 & 0 & 2 & 3 \\
\hline Native & $\mathrm{EP}$ & Onagraceae & Ludwigia & Ludwigia $x$ taiwanensis & 0 & 0 & 0 & 0 & 1 & 2 & 0 & 0 & 0 & 0 & 2 & 3 \\
\hline Native & $\mathrm{EP}$ & Guttiferae & Hypericum & Hypericum japonicum & 0 & 0 & 0 & 0 & 0 & 0 & 2 & 0 & 0 & 1 & 2 & 3 \\
\hline Native & $\mathrm{EP}$ & Commelinaceae & Murdannia & Commelina diffusa & 0 & 4 & 2 & 0 & 0 & 1 & 0 & 0 & 0 & 0 & 2 & 3 \\
\hline Native & $\mathrm{EP}$ & Asteraceae & Bidens & Bidens tripartita & 0 & 0 & 0 & 0 & 0 & 0 & 2 & 1 & 0 & 0 & 2 & 3 \\
\hline Native & $\mathrm{EP}$ & Poaceae & Alopecurus & Alopecurus aequalis & 0 & 1 & 1 & 0 & 0 & 0 & 0 & 0 & 0 & 2 & 2 & 3 \\
\hline Native & $\mathrm{EP}$ & Araceae & Acorus & ${ }^{*}$ Acorus calamus & 5 & 4 & 1 & 0 & 0 & 0 & 2 & 0 & 0 & 0 & 2 & 3 \\
\hline Native & $\mathrm{EP}$ & Scrophulariaceae & Veronica & Veronica anagallis-aquatica & 0 & 2 & 3 & 0 & 0 & 0 & 0 & 0 & 0 & 0 & 1 & 3 \\
\hline Native & $\mathrm{EP}$ & Cyperaceae & Schoenoplectus & Schoenoplectus triqueter & 0 & 0 & 0 & 0 & 0 & 0 & 0 & 0 & 3 & 0 & 1 & 3 \\
\hline Native & $\mathrm{EP}$ & Salicaceae & Salix & Salix chaenomeloides & 0 & 0 & 0 & 0 & 0 & 0 & 0 & 3 & 0 & 0 & 1 & 3 \\
\hline Native & $\mathrm{EP}$ & Cyperaceae & Cyperus & Cyperus odoratus & 0 & 2 & 3 & 0 & 0 & 0 & 0 & 0 & 0 & 0 & 1 & 3 \\
\hline Native & $\mathrm{EP}$ & Cyperaceae & Cyperus & Cyperus eragrostis & 0 & 2 & 3 & 0 & 0 & 0 & 0 & 0 & 0 & 0 & 1 & 3 \\
\hline Native & $\mathrm{EP}$ & Cyperaceae & Carex & Carex heterolepis & 0 & 0 & 3 & 0 & 0 & 0 & 0 & 0 & 0 & 0 & 1 & 3 \\
\hline
\end{tabular}




\section{Continued}

\begin{tabular}{|c|c|c|c|c|c|c|c|c|c|c|c|c|c|c|c|c|}
\hline Native & $\mathrm{EP}$ & Polygonaceae & Polygonum & Polygonum jucundum & 0 & 0 & 0 & 1 & 0 & 0 & 0 & 0 & 1 & 0 & 2 & 2 \\
\hline Native & $\mathrm{EP}$ & Polygonaceae & Polygonum & Polygonum barbatum & 0 & 0 & 1 & 0 & 0 & 1 & 0 & 0 & 0 & 0 & 2 & 2 \\
\hline Native & $\mathrm{EP}$ & Commelinaceae & Murdannia & Murdannia bracteata & 0 & 0 & 0 & 0 & 0 & 0 & 0 & 0 & 1 & 1 & 2 & 2 \\
\hline Native & $\mathrm{EP}$ & Onagraceae & Ludwigia & Ludwigia epilobioides & 0 & 0 & 0 & 0 & 0 & 0 & 1 & 1 & 0 & 0 & 2 & 2 \\
\hline Native & $\mathrm{EP}$ & Campanulaceae & Lobelia & Lobelia nummularia & 0 & 0 & 0 & 0 & 0 & 0 & 1 & 0 & 0 & 1 & 2 & 2 \\
\hline Native & $\mathrm{EP}$ & Scrophulariaceae & Lindernia & Lindernia antipoda & 0 & 1 & 1 & 0 & 0 & 0 & 0 & 1 & 0 & 0 & 2 & 2 \\
\hline Native & $\mathrm{EP}$ & Saururaceae & Houttuynia & Houttuynia cordata & 0 & 0 & 0 & 0 & 0 & 0 & 1 & 0 & 0 & 1 & 2 & 2 \\
\hline Native & $\mathrm{EP}$ & Cyperaceae & Fimbristylis & $\begin{array}{c}\text { Fimbristylis } \\
\text { quinquangularis }\end{array}$ & 0 & 0 & 0 & 0 & 0 & 0 & 1 & 1 & 0 & 0 & 2 & 2 \\
\hline Native & $\mathrm{EP}$ & Cyperaceae & Fimbristylis & Fimbristylis aestivalis & 0 & 2 & 0 & 0 & 1 & 1 & 0 & 0 & 0 & 0 & 2 & 2 \\
\hline Native & $\mathrm{EP}$ & Commelinaceae & Commelina & Commelina benghalensis & 0 & 0 & 0 & 0 & 0 & 0 & 1 & 1 & 0 & 0 & 2 & 2 \\
\hline Native & $\mathrm{EP}$ & Typhaceae & Typha & Typha orientalis & 0 & 0 & 0 & 0 & 0 & 0 & 0 & 2 & 0 & 0 & 1 & 2 \\
\hline Native & $\mathrm{EP}$ & Alismataceae & Sagittaria & $\begin{array}{c}\text { Sagittaria trifolia subsp. } \\
\text { leucopetala }\end{array}$ & 0 & 0 & 0 & 0 & 0 & 0 & 0 & 2 & 0 & 0 & 1 & 2 \\
\hline Native & $\mathrm{EP}$ & Polygonaceae & Polygonum & Polygonum kawagoeanum & 2 & 2 & 0 & 0 & 0 & 0 & 0 & 0 & 0 & 2 & 1 & 2 \\
\hline Native & $\mathrm{EP}$ & Poaceae & Coix & Coix lacryma-jobi & 0 & 0 & 2 & 0 & 0 & 0 & 0 & 0 & 0 & 0 & 1 & 2 \\
\hline Native & $\mathrm{EP}$ & Lamiaceae & Scutellaria & Scutellaria barbata & 0 & 0 & 0 & 0 & 0 & 0 & 0 & 0 & 0 & 1 & 1 & 1 \\
\hline Native & $\mathrm{EP}$ & Polygonaceae & Rumex & Rumex japonicus & 0 & 0 & 0 & 0 & 0 & 0 & 0 & 1 & 0 & 0 & 1 & 1 \\
\hline Native & $\mathrm{EP}$ & Lythraceae & Rotala & Rotala rosea & 0 & 0 & 0 & 0 & 0 & 0 & 1 & 0 & 0 & 0 & 1 & 1 \\
\hline Native & $\mathrm{EP}$ & Brassicaceae & Rorippa & Rorippa indica & 1 & 1 & 0 & 1 & 0 & 0 & 0 & 0 & 0 & 0 & 1 & 1 \\
\hline Native & $\mathrm{EP}$ & Polygonaceae & Polygonum & Polygonum sieboldii & 0 & 0 & 0 & 0 & 0 & 0 & 1 & 0 & 0 & 0 & 1 & 1 \\
\hline Native & $\mathrm{EP}$ & Poaceae & Paspalum & Paspalum thunbergii & 0 & 2 & 0 & 0 & 0 & 1 & 0 & 0 & 0 & 0 & 1 & 1 \\
\hline Native & $\mathrm{EP}$ & Campanulaceae & Lobelia & Lobelia chinensis & 0 & 0 & 0 & 0 & 0 & 0 & 0 & 0 & 1 & 0 & 1 & 1 \\
\hline Native & $\mathrm{EP}$ & Balsaminaceae & Impatiens & Impatiens chinensis & 0 & 0 & 0 & 0 & 0 & 0 & 1 & 0 & 0 & 0 & 1 & 1 \\
\hline Native & $\mathrm{EP}$ & Acanthaceae & Hygrophila & Hygrophila erecta & 0 & 0 & 0 & 1 & 0 & 0 & 0 & 0 & 0 & 0 & 1 & 1 \\
\hline Native & $\mathrm{EP}$ & Cyperaceae & Fuirena & Fuirena umbellata & 0 & 0 & 0 & 0 & 1 & 0 & 0 & 0 & 0 & 0 & 1 & 1 \\
\hline Native & $\mathrm{EP}$ & Cyperaceae & Eleocharis & Eleocharis yokoscensis & 0 & 0 & 0 & 0 & 0 & 0 & 1 & 0 & 0 & 0 & 1 & 1 \\
\hline Native & $\mathrm{EP}$ & Cyperaceae & Eleocharis & Eleocharis atropurpurea & 0 & 0 & 0 & 0 & 0 & 0 & 0 & 0 & 0 & 1 & 1 & 1 \\
\hline Native & $\mathrm{EP}$ & Cyperaceae & Cyperus & Cyperus pilosus & 0 & 0 & 0 & 0 & 0 & 0 & 1 & 0 & 0 & 0 & 1 & 1 \\
\hline Native & $\mathrm{EP}$ & Cyperaceae & Cyperus & Cyperus imbricatus & 0 & 0 & 0 & 1 & 0 & 0 & 0 & 0 & 0 & 0 & 1 & 1 \\
\hline Native & $\mathrm{EP}$ & Cyperaceae & Cyperus & Cyperus compressus & 0 & 0 & 0 & 0 & 0 & 0 & 1 & 0 & 0 & 0 & 1 & 1 \\
\hline Native & $\mathrm{EP}$ & Cyperaceae & Cyperus & Cyperus compactus & 0 & 0 & 0 & 0 & 1 & 0 & 0 & 0 & 0 & 0 & 1 & 1 \\
\hline Native & $\mathrm{EP}$ & Pteridaceae & Ceratopteris & Ceratopteris thalictroides & 0 & 1 & 0 & 0 & 1 & 0 & 0 & 0 & 0 & 0 & 1 & 1 \\
\hline Native & $\mathrm{EP}$ & Cyperaceae & Carex & Carex baccans & 0 & 0 & 0 & 0 & 0 & 0 & 1 & 0 & 0 & 0 & 1 & 1 \\
\hline Alien & FP & Pontederiaceae & Eichhornia & Eichhornia crassipes & 2 & 1 & 3 & 5 & 5 & 5 & 3 & 0 & 3 & 3 & 7 & 27 \\
\hline Alien & $\mathrm{FP}$ & Araceae & Pistia & Pistia stratiotes & 5 & 5 & 2 & 0 & 2 & 3 & 2 & 0 & 1 & 0 & 5 & 10 \\
\hline Alien & EP & Acanthaceae & Ruellia & ${ }^{\star}$ Ruellia brittoniana & 5 & 5 & 1 & l & I & l & 1 & 1 & l & I & 1 & I \\
\hline Alien & $\mathrm{EP}$ & Alismataceae & Echinodorus & ${ }^{\star}$ Echinodorus grisebachii & 4 & 4 & 1 & l & I & l & l & l & l & I & 1 & l \\
\hline
\end{tabular}




\section{Continued}

\begin{tabular}{|c|c|c|c|c|c|c|c|c|c|c|c|c|c|c|c|c|}
\hline Alien & $\mathrm{EP}$ & Apiaceae & Hydrocotyle & ${ }^{\star}$ Hydrocotyle vulgaris & 4 & 4 & l & l & l & 1 & l & 1 & / & / & / & I \\
\hline Alien & $\mathrm{EP}$ & Cannaceae & Canna & ${ }^{*}$ Canna glauca & 5 & 5 & / & l & l & / & l & / & / & l & / & I \\
\hline Alien & $\mathrm{EP}$ & Cyperaceae & Cyperus & ${ }^{\star}$ Cyperus prolifer & 4 & 4 & / & l & I & I & I & I & I & / & / & I \\
\hline Alien & $\mathrm{EP}$ & Cyperaceae & Cyperus & ${ }^{\star}$ Cyperus papyrus & 4 & 4 & / & l & l & l & l & / & / & / & / & l \\
\hline Alien & $\mathrm{EP}$ & Haloragaceae & Myriophyllum & ${ }^{\star}$ Myriophyllum aquaticum & 4 & 4 & / & l & l & / & l & / & / & / & / & I \\
\hline Alien & $\mathrm{EP}$ & Marantaceae & Thalia & *Thalia geniculata & 4 & 4 & / & l & l & / & l & I & / & / & / & I \\
\hline Alien & $\mathrm{EP}$ & Marantaceae & Thalia & *Thalia dealbata & 5 & 5 & / & l & / & / & / & / & / & / & / & l \\
\hline Alien & $\mathrm{EP}$ & Nymphaeaceae & Nymphaea & ${ }^{*}$ Nymphaea $s p$ & 4 & 4 & / & l & l & I & l & I & / & / & / & I \\
\hline Alien & $\mathrm{EP}$ & Pontederiaceae & Pontederia & ${ }^{*}$ Pontederia cordata & 5 & 5 & / & / & / & I & l & / & / & / & / & I \\
\hline Alien & $\mathrm{Ep}$ & Scrophulariaceae & Angelonia & * Angelonia angustifolia & 4 & 4 & / & l & l & / & / & / & / & / & / & I \\
\hline Alien & $\mathrm{EP}$ & Amaranthaceae & Alternanthera & $\begin{array}{l}\text { Alternanthera } \\
\text { philoxeroides }\end{array}$ & 3 & 4 & 4 & 3 & 4 & 5 & 0 & 2 & 2 & 3 & 7 & 23 \\
\hline Alien & $\mathrm{EP}$ & Asteraceae & Bidens & Bidens pilosa var.radiata & 3 & 5 & 5 & 4 & 3 & 5 & 0 & 0 & 0 & 3 & 5 & 20 \\
\hline Alien & $\mathrm{EP}$ & Poaceae & Pennisetum & Pennisetum purpureum & 0 & 0 & 3 & 5 & 3 & 5 & 0 & 0 & 0 & 0 & 4 & 16 \\
\hline Alien & $\mathrm{EP}$ & Poaceae & Brachiaria & Brachiaria mutica & 0 & 0 & 5 & 5 & 0 & 5 & 0 & 0 & 0 & 0 & 3 & 15 \\
\hline Alien & $\mathrm{EP}$ & Asteraceae & Wedelia & Wedelia trilobata & 0 & 5 & 5 & 3 & 0 & 5 & 0 & 0 & 1 & 0 & 4 & 14 \\
\hline Alien & $\mathrm{EP}$ & Asteraceae & Ageratum & Ageratum conyzoides & 0 & 2 & 3 & 0 & 2 & 2 & 2 & 0 & 1 & 0 & 5 & 10 \\
\hline Alien & $\mathrm{EP}$ & Asteraceae & Soliva & Soliva anthemifolia & 2 & 2 & 1 & 0 & 2 & 2 & 0 & 0 & 0 & 0 & 3 & 5 \\
\hline Alien & $\mathrm{EP}$ & Asteraceae & Gymnocoronis & $\begin{array}{l}\text { Gymnocoronis } \\
\text { spilanthoides }\end{array}$ & 0 & 0 & 0 & 0 & 0 & 0 & 0 & 0 & 5 & 0 & 1 & 5 \\
\hline Alien & $\mathrm{EP}$ & Asteraceae & Aster & Aster subulatus & 0 & 1 & 1 & 0 & 1 & 0 & 0 & 0 & 0 & 0 & 2 & 2 \\
\hline Alien & $\mathrm{EP}$ & Asteraceae & Pluchea & Pluchea sagittalis & 0 & 1 & 2 & 0 & 0 & 0 & 0 & 0 & 0 & 0 & 1 & 2 \\
\hline Alien & $\mathrm{EP}$ & Asteraceae & Synedrella & Synedrella nodiflora & 0 & 0 & 0 & 0 & 1 & 0 & 0 & 0 & 0 & 0 & 1 & 1 \\
\hline Alien & $\mathrm{EP}$ & Cyperaceae & Cyperus & ${ }^{*}$ Cyperus involucratus & 3 & 2 & 0 & 1 & 0 & 0 & 0 & 0 & 0 & 0 & 1 & 1 \\
\hline
\end{tabular}

